\title{
ANALGESIC AND ANTI-INFLAMMATORY EFFECTS OF AN EXTRACT OF FADOGIA AGRESTIS IN RATS
}

\begin{abstract}
Received 03.12.09
Analgesic and anti-inflammatory activities of an aqueous extract produced from Fadogia agrestis (family Rubiaceae) stem bark were investigated using animal models. Significant dose-dependent increases in the reaction time in the tail-flick test and inhibition of writhing in the visceral pain test (i.p. injections of acetic acid) with $P$ up to $<0.001$, when compared with the control, were observed. In an anti-inflammatory investigation, we also found significant dose-dependent inhibitions in the carrageenan-induced paw edema and cotton-pellet granuloma tests. The extract in the highest non-sedative dose tested $(200 \mathrm{mg} / \mathrm{kg})$ demonstrated a potency comparable with that of a reference analgesic anti-inflammatory drug, acetyl salicylate (Aspirin, $100 \mathrm{mg} / \mathrm{kg}$ ). Phytochemical screening revealed the presence of alkaloids and saponins in the extract. The relieving effects of Fadogia are probably mediated by the influences of active components of the extract on both central and peripheral nociceptive/ antinociceptive neural mechanisms. Therefore, our investigation explains the rationale behind the ethnomedicinal usage of the mentioned plant to relieve pain and inflammation, as claimed by local users, and shows that further studies of the mechanisms underlying the effects of the remedy tested are expedient.
\end{abstract}

Keywords: Fadogia agrestis (Schweinf. ex Hiern), analgesic and anti-inflammatory effects, tail-flick test, writhing, edema, granuloma.

\section{INTRODUCTION}

The quest for natural remedies has been on an increase in the 21 st century due to availability and affordability challenges associated with a number of orthodox remedies and also because of insufficient efficacy and the existence of significant side effects typical of many "standard" drugs. Pain and inflammation are common ailments to which remedies are being sought on everyday basis. Inflammation, a major causative agent of human morbidity and mortality, such as the systemic inflammatory response syndrome (SIRS) and multiple organ dysfunction syndrome (MODS) [1], is prevalent in many localities in the developing countries as a result of inadequate health care and a low level of health education. In response to these challenges, many people "turn to nature." One of the local remedies sought in many African localities is the

\footnotetext{
${ }^{1}$ Faculty of Basic Medical Sciences, Ladoke Akintola University of Technology, Ogbomoso, Nigeria.

${ }^{2}$ University of Benin, Benin, Nigeria.

Correspondence should be addressed to O. K. Okojie

(e-mail: pintos4live@yahoo.com).
}

stem bark of Fadogia agrestis (family Rubiaceae), a shrub widely distributed in the forest coast of West Africa. This plant was reported to be effective for wound healing and against diarrhea. Certain effects of the plant with respect to the sexual sphere were also claimed $[2,3]$ and proven in a scientific research. Since no literature is currently available to substantiate possible analgesic and anti-inflammatory properties of preparations obtained from the above plant, our study was aimed at experimental testing the respective properties of this plant as claimed by local users.

\section{METHODS}

Plant materials. The plant materials were collected in Gambari, a suburb of Ogbomoso city in South Western Nigeria, in February, 2009. The plant was identified as Fadogia agrestis (Schveinf. ex Hiern) and authenticated at the Forestry Research Institute of Nigeria (FRIN), Ibadan. A voucher specimen was deposited at the Institute.

Extract preparation. The stem bark of Fadogia agrestis was dried at $40^{\circ} \mathrm{C}$ to a constant weight and 
reduced to a coarse powder with the aid of a laboratory grinder. An aqueous extract of the plant was obtained by decoction in distilled water for $48 \mathrm{~h}$ at room temperature. The obtained extract was filtered and concentrated in a steam bath. Phytochemical screening of the extract for identification of the constituents using a standard protocol was performed [4].

Chemicals. Aspirin and carrageenan were purchased from Sigma (Great Britain). All other chemicals were of an analytical grade and procured locally.

Animals. Prepubertal male Wistar rats aged about 4 weeks and weighing 70-100 g were used in investigating the analgesic activity considering that a pain-protection influence provided by testosterone in adult rats was found in our earlier study [5]. Adult rats weighing 200-250 g were used for examination of the anti-inflammatory properties of the extract. All animals were kept at $23 \pm 2^{\circ} \mathrm{C}$ and a $12 / 12 \mathrm{~h} \mathrm{light/dark} \mathrm{cycle}$ in the preclinical animal house of the Ladoke Akintola University of Technology, Ogbomoso (Nigeria). The animals were fed with standard rat pellet food and provided with water ad libitum; they were acclimatized for at least one week before the experimental sessions in the laboratory. All the experimental procedures were done following the experimental guidelines of the Institutional Animal Ethics Committee (IAEC).

Each experimental procedure was applied to 5 animal groups with 5 rats in each group. Group 1 served as the control; groups 2-4 (treatment groups) were subjected to the actions of the Fadogia extract. All the doses mentioned below $(50,100$, or $200 \mathrm{mg} / \mathrm{kg}$ ) are indicated for a dry residue of the extract. Group 5 (reference group) was treated with Aspirin (100 mg/kg). Both Aspirin and the extract were administered perorally using an oral cannula.

Tail immersion (tail-flick) test. The standard procedure was used. Each animal for this procedure was held in a suitable soft restrainer with the tail extending out. The tail was up to $5 \mathrm{~cm}$ dipped into a beaker with hot water maintained at $55 \pm 0.1{ }^{\circ} \mathrm{C}$ [6]. The time taken for the rat to withdraw the tail (sec) was considered the reaction time. Testings in groups 2-5 were carried out 30,60 , and $120 \mathrm{~min}$ after administration of the studied extract or Aspirin.

Acetic acid-induced writhing test. Thirty minutes after administrations of the tested extract or Aspirin, $1 \%$ solution of acetic acid was i.p. injected into each rat at a dose of $1 \mathrm{mg} / 100 \mathrm{~g}$ body mass [7]. The number of writhing motor phenomena, such as contortions and stretching, were counted within a 15-min-long test interval. The normalized intensity of inhibition of writhings was calculated, expressed as percentage, and compared with the controls using the relation $(\mathrm{Nc}-\mathrm{Nt}) / \mathrm{Nc} \cdot 100 \%$, where $\mathrm{Nc}$ and $\mathrm{Nt}$ are mean numbers of writhings in the control (group 1) and test groups 2-5, respectively.

Carrageenan-induced paw edema test. Acute inflammation was produced in the hindlimb by injection of $1 \%$ solution of carrageenan $(0.1 \mathrm{ml} / 100 \mathrm{~g}$ body mass $)$ into the plantar surface of the hind paw [8] $30 \mathrm{~min}$ after administrations of the extract or Aspirin. The paw edema was measured at the intervals of $1,2,3$, and $4 \mathrm{~h}$ using a plethysmometer. The normalized intensity of suppression of paw edema among different animal groups was compared using the formula analogous to that mentioned above: $(\mathrm{Vc}-\mathrm{Vt}) / \mathrm{Nc} \cdot 100 \%$, where $\mathrm{Vc}$ and $\mathrm{Vt}$ are mean increases in the paw volume in the control and test groups, respectively.

Cotton pellet granuloma test. Rats were anesthetized by i.p. ketamine injections, and 2-cm-long incision was made on the rats' groin region. An autoclaved cotton pellet weighing $50 \mathrm{mg}$ was implanted in this region of each rat [9]. All the animals in each group were dosed once for 7 days. On the 8 th day, animals were sacrificed by cervical dislocation, and the cotton pellet along with the granuloma tissue was extracted and dried in an oven at $55^{\circ} \mathrm{C}$ for $24 \mathrm{~h}$. The resulting cotton pellet weights were compared with the control, and the normalized intensity of inhibition of the development of granuloma by the tested remedies was calculated.

The numerical data are represented as means \pm \pm s.e.m.; Student's $t$-test was performed, and $P<0.05$ values were considered as confirming a significant intergroup difference.

\section{RESULTS}

Introduction of the extract of Fadogia agrestis bark to experimental rats led to significant suppression of the tail-flick reflex induced by noxious stimulation of thermonociceptors in the tail skin. The effect demonstrated a clear dose dependence. When 50 or 100 $\mathrm{mg}$ of the extract dry residue per $1 \mathrm{~kg}$ of the body mass were introduced, the delay of the tail flick movement showed twofold to threefold increases or more, as compared with the mean delay in the control group 1 . When the highest tested dose (200 mg/kg, group 4) was used, the tail flick delay reached $490-577 \%$ of that in the control group. Thus, the analgesic effect of the extract introduced in a dose of $200 \mathrm{mg} / \mathrm{kg}$ was weaker than 

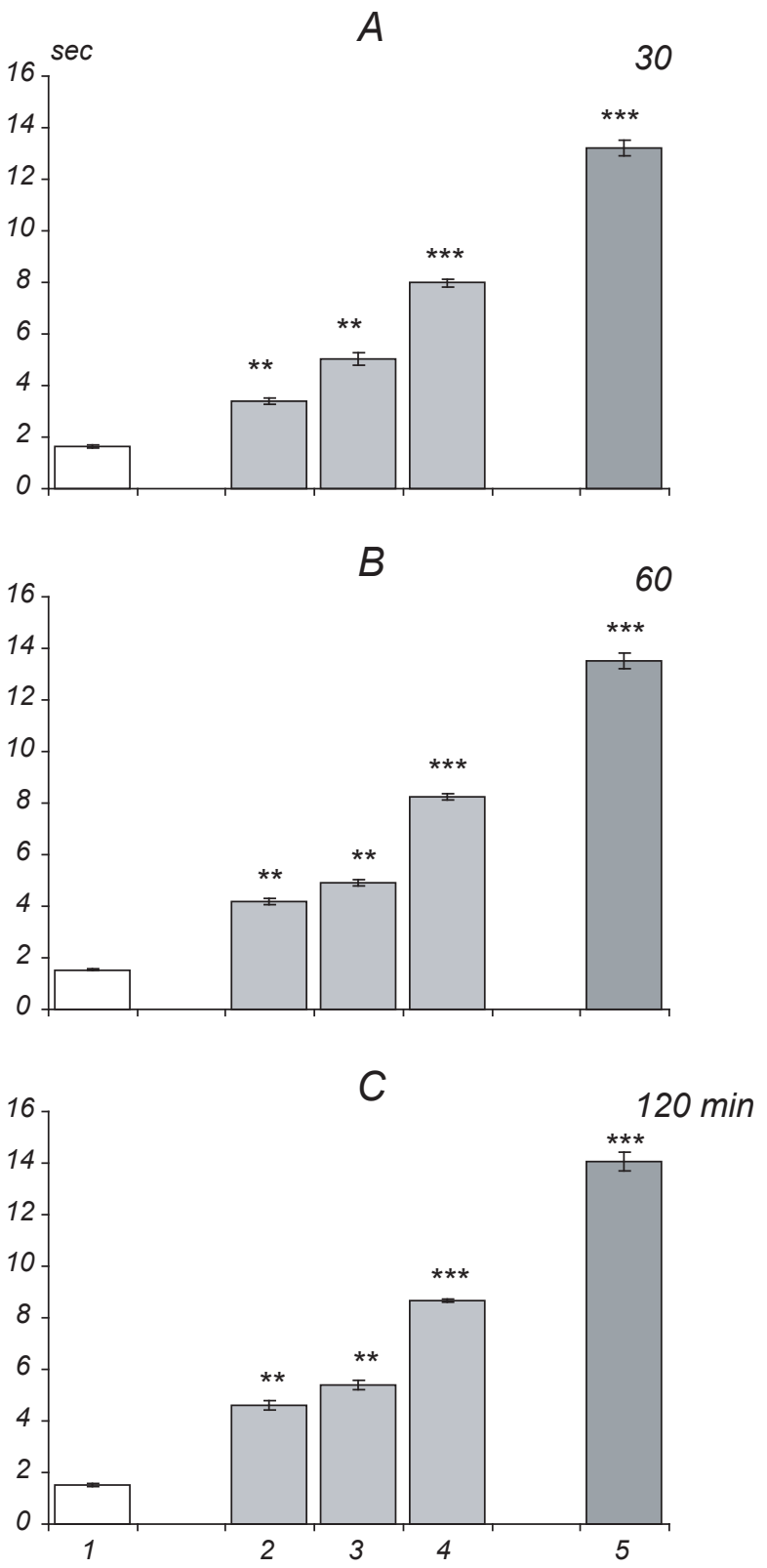

Fig. 1. Analgesic activity of the extract of Fadogia agrestis in the tail-flick test. Diagrams of the mean delays (sec) of tail-flick movements ( \pm s.e.m.) observed in different groups of animals (5 rats each) 30,60 , and $120 \mathrm{~min}$ (shown at the right, A-C) after introductions of 50,100 , and $200 \mathrm{mg} / \mathrm{kg}$ of the extract (groups 2-4, respectively) and of $100 \mathrm{mg} / \mathrm{kg}$ Aspirin (group 5). The data for the control group 1 are also shown. Two and three asterisks show cases of significant differences with $P<0.01$ and $P<0.001$ from the values in the control group 1 .

Р и с. 1. Знеболювальна активність екстракту Fadogia agrestis у тесті відсмикування хвоста. that of $100 \mathrm{mg} / \mathrm{kg}$ Aspirin (the latter latency increase in the test used was eight- to ninefold or more) but quite comparable with the effect of the above-mentioned well-known and extensively used ("classic") antinociceptive and anti-inflammatory drug. The effects of the extract were rather stable within the observation period $(2 \mathrm{~h})$ and even became somewhat more intense within this time interval (Fig. 1A-C).

In the test where visceral pain was induced (i.p. injection of acetic acid solution), the Fadogia extract also demonstrated significant analgesic effects. Thirty minutes after extract administration, introductions of all the three doses used resulted in decreases in the number of writhing motor effects observed within a 15-min-long observation interval. The antinociceptive effect was relatively mild (a $12.6 \%$ decrease) at the lowest dose $(50 \mathrm{mg} / \mathrm{kg})$ used; but in the case where $200 \mathrm{mg} / \mathrm{kg}$ of the extract dry residue were introduced, the number of writhings dropped more than two times. For comparison, $100 \mathrm{mg} / \mathrm{kg}$ Aspirin caused an about threefold decrease in the number of writhings (Fig. 2).

In control rats, injection of carrageenan $(0.2 \mathrm{ml}$ of $1 \%$ solution per $100 \mathrm{~g}$ of the body mass) into the hindpaw plantar surface resulted in the development of edema in the injured limb. One hour after carrageenan injection, the edema volume was, on average, $1.81 \pm 0.01 \mathrm{ml}$, and the volume increased to $1.94 \pm 0.01 \mathrm{ml}$ (a $7.2 \%$ rise, $P<0.05)$ on the 4 th $\mathrm{h}$. The Fadogia extract in the $50 \mathrm{mg} / \mathrm{kg}$ dose decreased the edema volume within this

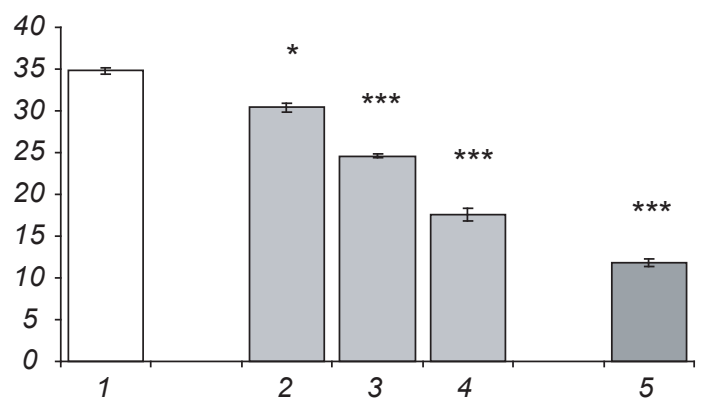

Fig. 2. Analgesic activity of the Fadogia extract in the acetic acidinduced writhing test. Diagrams of the mean numbers of writhings within a 15 -min-long observation period $30 \mathrm{~min}$ after introduction of the remedies tested. One asterisk shows significant difference with $P<0.05$ from the values in group 1 . Other designations are similar to those in Fig. 1.

Р и с. 2. Знеболювальна активність екстракту Fadogia agrestis у тесті корчів, викликаних уведенням оцтової кислоти. 

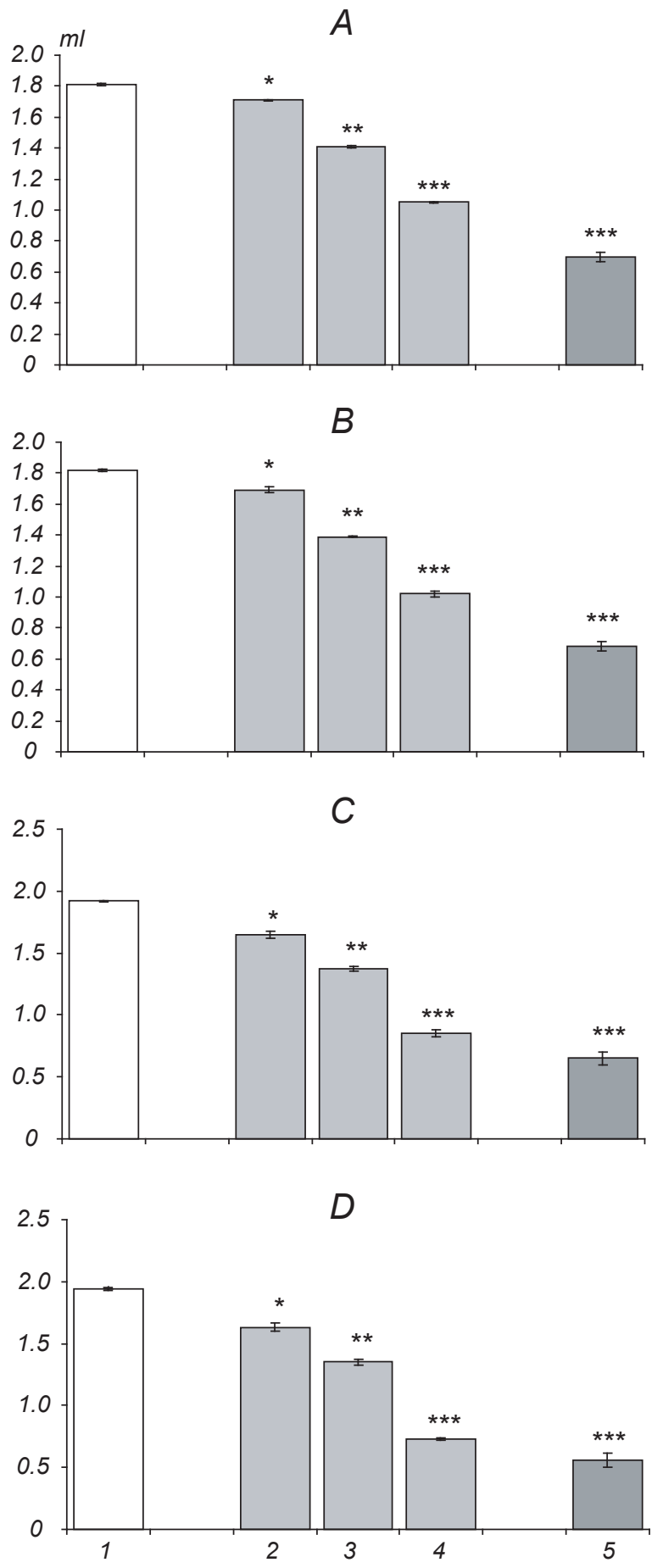

Fig. 3. Anti-inflammatory activity of the Fadogia extract in the carrageenan-induced paw edema test. Diagrams of mean increases in the paw volume $(\mathrm{ml})$ resulting from edema $1,2,3$, and $4 \mathrm{~h}$ after carrageenan injection (A-D, respectively). Designations are similar to those in Figs. 1 and 2.

Р и с. 3. Протизапальна активність екстракту Fadogia agrestis у тесті набряку лапи, індукованого введенням карагеніну.

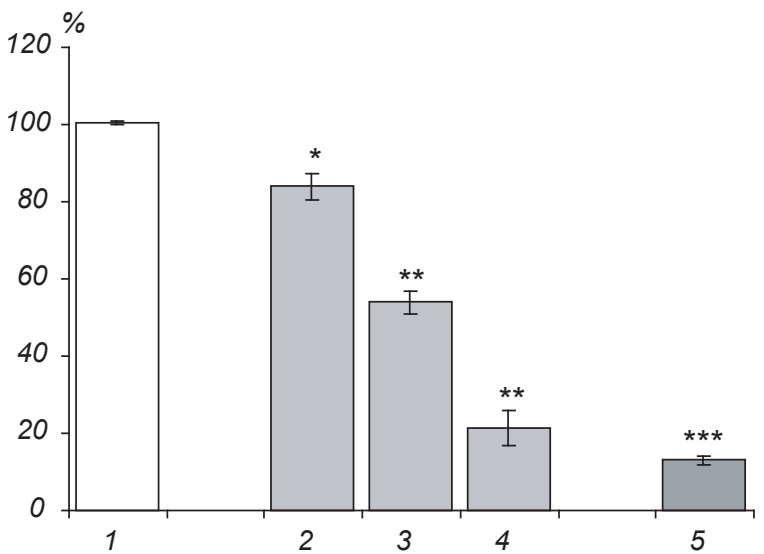

Fig. 4. Anti-inflammatory activity of the Fadogia extract in the cotton pellet granuloma test. Diagrams of normalized mean weights of the pellet (\%; weight in the control group 1 is taken as $100 \%$ ). Other designations are similar to those in Fig. 1-3.

Р и с. 4. Протизапальна активність екстракту Fadogia agrestis у тесті гранульоми, індукованої імплантацією ватного тампона.

period by 5.5 to $16.0 \%$, while the respective decrease at the $200 \mathrm{mg} / \mathrm{kg}$ dose varied from 42.0 to $62.4 \%$. The latter effect was again quite comparable with a positive effect of Aspirin in the dose used, namely from 61.3 to $71.1 \%$ (Fig. 3A-D).

These results agreed well with the results of the cotton pellet granuloma test. At the extract dry residue doses 50,100 , and $200 \mathrm{mg} / \mathrm{kg}$, the normalized masses of the pellet, as compared with the corresponding index in the control group 1, were smaller by 16.5 , 46.3 , and $78.9 \%$, respectively. Administration of Aspirin provided a $87.1 \%$ decrease in the pellet mass; so, the anti-inflammatory efficacy of the extract in the highest dose used was again quite comparable with that of Aspirin in a rather high dosage.

\section{DISCUSSION}

The results of our study showed that the aqueous extract of Fadogia agrestis (Schweinf. ex Hiern) stem bark induces considerable dose-dependent analgesic effects against the writhing syndrome observed in the acetic acid test. These abdominal writhes, which result from the action of severe visceral pain [10], are probably suppressed mostly by a peripheral analgesic effect of the remedies tested [11-13]. In peripheral tissues, the development of pain is mostly a consequence 
of sensitization of the chemosensitive nociceptors by prostaglandins [14]. The result obtained in this model, therefore, suggests that the pain-suppressing effect of the extract may be due to inhibition of prostaglandin synthesis. However, our suggestion on an analgesic effect of the extract was not based on this model alone, because several compounds, such as tricyclic antidepressants [15] and histamine [16], also exhibit suppression of the writhing syndrome. A more specific model (tail immersion test) based on noxious stimulation of thermonociceptors was employed to investigate the analgesic potential of the extract against this type of pain. The result showed clear dosedependent increases in the reaction time in the above test. This model provides an evidence that the extract exerts not only peripheral effects on nociceptors but probably possesses some central action on the spinal and cerebral antinociception neuronal systems [17].

We also investigated the anti-inflammatory potential of the extract. Inflammatory events involve microvascular changes with increased vascular permeability, flow of exudation (including plasmatic proteins), and increase in the amounts of endogenous mediators [18]. Non-steroidal antiinflammatory drugs (NSAIDs) are common means against superficial nociception and inflammation. NSAIDs alleviate hyperalgesic symptoms associated with inflammation by inhibiting the cyclooxygenase activity and by resultant inhibition of prostaglandin synthesis from arachidonic acid [19]. Our results demonstrated intense dose-dependent inhibitions of paw edema (in the carrageenan-induced paw edema model) and the development of granuloma (in cotton pellet granuloma model). The maximum nonsedative dose offered the highest level of protection in both models of inflammation, probably mostly by inhibiting prostaglandin synthesis.

As was mentioned above, the Fadogia extract exerted analgesic and anti-inflammatory effects quite comparable in their intensity with the effects of the "standard" NSAID Aspirin, one of the most extensively used remedies. It should be taken into account that we used in our tests a rather high dose of this drug (which is much higher than the doses usually introduced in clinics) to provide the most demonstrative antinociceptive and anti-inflammatory effect in the reference animal group. Naturally, the Fadogia extract can demonstrate even stronger analgesic effects, as compared with those of smaller Aspirin doses.

Phytochemical screening results confirmed that significant amounts of alkaloids and saponins, the constituents which have been reported in other members of the botanical family Rubiaceae and identified as potent analgesics, are present in the Fadogia extract; much lesser amounts of flavonoids and antraquinone were also found [20,21]. These constituents could be responsible for analgesic and anti-inflammatory potentials of the studied extract. We hereby suggest that further studies on characterization and identification of the molecular structure of different constituents present in the extract and the possibilities for its applicability in medicinal chemistry and for the development of novel remedies are rather expedient. Of course, this also presupposes the necessity of technological perfection of preparation of clinically usable drugs from plant raw materials and detailed clinical testing of such remedies.

Acknowledgments. We express our gratitude to the head of the Department of Physiology and Management of the Preclinical Animal House at the Ladoke Akintola University of Technology, Ogbomoso (Nigeria).

\section{О. А. Ойєкунле , А. К. Окойє ${ }^{2}$, Ю. С. Удо}

\section{ЗНЕБОЛЮВАЛЬНІ Й ПРОТИЗАПАЛЬНІ ЕФЕКТИ ЕКСТРАКТУ FADOGIA AGRESTIS У ЩУРIВ}

${ }^{1}$ Технологічний університет Ладоке Акінтола, Огбомозо (Нігерія).

${ }^{2}$ Бенінський університет (Нігерія).

P е 3 ю м е

Знеболювальна й протизапальна активність водного екстракту, виготовленого 3 кори Fadogia agrestis (сімейство Маренові), вивчалася на щурах з використанням різних моделей болю та запалення. Екстракт забезпечував дозозалежне збільшення часу реакції в тесті відсмикування хвоста та посилення гальмування корчів у тесті вісцерального болю (індукованого внутрішньоочеревинними ін'єкціями оцтової кислоти) $3 P$ аж до $<0.001$ порівняно 3 контролем. Вивчаючи протизапальні ефекти екстракту Fadogia, ми також виявили значне дозозалежне пригнічення запалення в тестах набряку лапи, індукованого введенням карагеніну, та розвитку гранульоми, індукованого імплантацією ватного тампона. Цей екстракт, застосований у найвищій неседативній дозі (200 мг/кг), демонстрував ефективність, цілком порівняну 3 такою еталонного знеболюючого i протизапального агента - ацетилсаліцилата (аспірину, 100 мг/кг). Фітохімічний скринінг дозволив нам виявити в екстракті присутність алкалоїдів, сапонінів та флавоноїдів. Знеболювальні ефекти Fadogia опосередковуються, вірогідно, впливами активних компонентів екстракту як на центральні, так і на периферичні нервові ноцицептивні/ антиноцицептивні механізми. Отже, результати наших досліджень логічно обгрунтовують ефекти використання 
згадуваної рослини в етнічній медицині з метою ослаблення болю й пригнічення запалення, а також свідчать про доцільність подальшого вивчення механізмів, що лежать в основі дії тестованого лікувального засобу.

\section{REFERENCES}

1. A. E. Baue, R. Durham, and E. Faist, "Systemic inflammatory response syndrome (SIRS), multiple organ dysfunction syndrome (MODS), multiple organ failure (MOF): Are we winning the battle?" Shock, 10, No. 2, 79-89 (1998).

2. F. R. Irvin, Woody Plants of Ghana, Oxford Univ. Press, London (1961).

3. M. T. Yakubu, M. A. Akanji, and A. T. Oladiji, "Aphrodisiac potentials of the aqueous extract of Fadogia agrestis (Schweinf. ex Hiern) stem in male albino rat," Asian J. Androl., 7, No. 4, 399-404 (2005).

4. J. B. Harborne, Phytochemical Methods, Chapman and Hall, London, New York (1984).

5. O. A. Oyekunle, G. F. Ibironke, S. F. Ige, et al., "Relationship between the plasma testosterone level and pain reaction times in male rats," Neurophysiology, 41, No. 3, 193-195 (2009).

6. J. B. Periyanayagam, S. K. Sharma, A. Joseph, and A. J. Christina, "Evaluation of antipyretic and analgesic activity of Emblica officinalis (Gaertn.),"J. Ethnopharmacol., 95, 83 (2004).

7. H. O. Collier, L. C. Dinneen, C. A. Johnson, and C. Scheider, "The abdominal contraction response and its suppression by antinociceptive drugs in the mouse," Br. J. Pharm. Chemother., 32, 295 (1968).

8. C. A. Winter and G. W. Risely, "Carrageenan-induced edema in hind paw of the rat as an assay for anti-inflammatory drug," Proc. Soc. Exp. Biol. Med., 111, 544 (1963).

9. H. Hosseinzadeh and G. Salamani, "Antinociceptive, antiinflammatory and acute toxicity effects of Zataria multiflora (Boiss) extracts in mice and rats," J. Ethnopharmacol., 73, 379-385 (2000).
10. L. Vyklicky, "Techniques for the study of pain in animals," in: Bonica, J. J. Liebeskind and J. C. Albe-Fessard (eds.), Adv. Pain Res. Ther., Raven Press, New York (1979), pp. 727-745.

11. A. H. Atta and A. Alkofahi, "Antinociceptive and antiinflammatory effects of some Jordanian medicinal plant extracts," J. Ethnopharmacol., 60, 117-124 (1997).

12. E. T. Wei, J. G. Kiang, P. Buchan, and T. W. Smith, "Corticotrophin-releasing factor inhibits neurogenic plasma extravasation in the rat paw," J. Pharmacol. Exp. Ther., 238, 783-787 (1986).

13. S. W. Hajare, C. Suresh, S. K. Tandan, et al., "Analgesic and anti-pyretic activities of Dalbergia sissoo leaves," Indian J. Pharmacol., 32, 357-360 (2000).

14. N. G. Maria Elena, S. E. Jose Arthur Da, C. Souccar, and J. L. Antonio, "Analgesic and anti-inflammatory activities of the aqueous extract of Plantango major L.," Int. J. Pharmacognosy, 35, 99-104 (1997).

15. R. N. Takahashi and M. M. Paz, "Influence of naloxone on the analgesic effects of antidepressants," Braz. J. Med. Biol. Res., 20, 607-610 (1987).

16. S. Y. Yeh, "Potentiation of pentazocine antinociception by tripelennamine in rat," J. Pharmacol. Exp. Ther., 235, 683-689 (1985).

17. R. A. Turner, Screening Methods in Pharmacology, Acad. Press, New York (1965).

18. G. Ciarino, "Multiple controls in inflammation: extracellular and intracellular phospholipase $\mathrm{A}_{2}$ inducible and constitutive cyclooxygenase and inducible nitric oxide synthase," Biochem. Pharmacol., 55, 111 (1988).

19. J. R. Vane, "Inhibition of prostaglandin synthesis as a mechanism of action for aspirin-like drugs," Nature, 231, 232 (1979).

20. L. B. Fernanda, A. K. Vitor, T. H. Amelia, and E. Elaine, "Analgesic properties of Umbellatine from Pschotria umbellata," Pharmaceutic. Biol., 40, No. 5, 336-341 (2002).

21. R. E. Schultes and R. F. Raffauf, The Healing Forest: Medicinal and Toxic Plants of the Northwest Amazonia, Dioscorides Press, Portland (1990). 